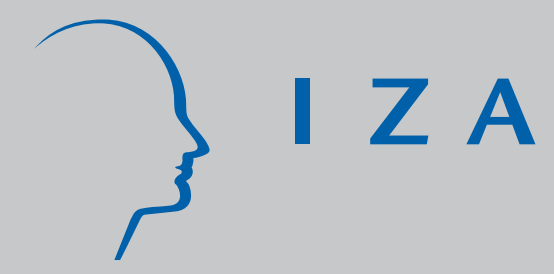

IZA DP No. 3180

Industry Churning and the Evolution of Cities:

Evidence for Germany

Sebastian Findeisen

J ens Suedekum

November 2007 


\title{
Industry Churning and the Evolution of Cities: Evidence for Germany
}

\author{
Sebastian Findeisen \\ University of Konstanz \\ Jens Suedekum \\ University of Duisburg-Essen, \\ University of Konstanz and IZA
}

Discussion Paper No. 3180
November 2007

IZA

P.O. Box 7240

53072 Bonn

Germany

Phone: +49-228-3894-0

Fax: +49-228-3894-180

E-mail: iza@iza.org

\begin{abstract}
Any opinions expressed here are those of the author(s) and not those of the institute. Research disseminated by IZA may include views on policy, but the institute itself takes no institutional policy positions.

The Institute for the Study of Labor (IZA) in Bonn is a local and virtual international research center and a place of communication between science, politics and business. IZA is an independent nonprofit company supported by Deutsche Post World Net. The center is associated with the University of Bonn and offers a stimulating research environment through its research networks, research support, and visitors and doctoral programs. IZA engages in (i) original and internationally competitive research in all fields of labor economics, (ii) development of policy concepts, and (iii) dissemination of research results and concepts to the interested public.
\end{abstract}

IZA Discussion Papers often represent preliminary work and are circulated to encourage discussion. Citation of such a paper should account for its provisional character. A revised version may be available directly from the author. 
IZA Discussion Paper No. 3180

November 2007

\section{ABSTRACT \\ Industry Churning and the Evolution of Cities: Evidence for Germany*}

In this paper we show that the recent model by Duranton (AER, 2007) performs remarkably well in replicating the city size distribution of West Germany, much better than the simple rank-size rule known as Zipf's law. The main mechanism of this theoretical framework is the "churning" of industries across cities. Little is known so far about the determinants of local industry turnover, however. We present an empirical analysis of the excess churning index for West German cities, which describes the strength of intra-city industry reallocations that has occurred over time. We find that human capital is a key driver of growth and local industrial change, but only among successful cities. Industrial change within unsuccessful cities is strongly driven by the disappearance of old-fashioned and declining industries such as agriculture or mining. On a more general level, our results suggest that the recent model by Duranton is a powerful description of the urban growth process. Still there are some aspects that are not captured by that model, which are at the core of other theories of urban growth.

JEL Classification: $\quad \mathrm{O} 18, \mathrm{R} 11, \mathrm{R} 12$

Keywords: $\quad$ industry turnover, urban growth, structural change, churning, city size distribution, Zipf's law

Corresponding author:

Jens Suedekum

Mercator School of Management

University of Duisburg-Essen

Lotharstraße 65

47057 Duisburg

Germany

E-mail: jens.suedekum@uni-due.de

\footnotetext{
* The authors thank seminar participants in Savannah and Halle. All remaining errors and shortcoming are solely our responsibility. This work was supported by a grant from the Ministry of Science, Research and the Arts of Baden-Württemberg (Az: 21-655.042-5-2/1) to Jens Suedekum.
} 


\section{1.) Introduction}

Due to various forms of localized increasing returns, most economic activity is concentrated in cities, and cities are the main engines of economic growth. Still there is no evidence that all economic activity within a country will eventually end up in one or a few large metropolitan areas. The data rather suggests that the distribution of city sizes remains remarkably stable over time, and is at least close to the famous rank-size rule known as "Zipf's law". Successful theories of urban growth all come to grips with this basic fact. ${ }^{1}$ A limitation of most existing approaches, however, is that they have little to say about how cities change their face - i.e., their industry composition - during the growth process, and how urban growth is related to (changes in) local economic structures. Yet, cities are to a large extent characterized by their economic structure, and growth depends on the performance of the local industries of which the city is composed (Simon 2004). Case studies like those by Glaeser (2005) in fact suggest that the success of cities can be well understood by their ability to adapt and to change ("reinvent”) their industry structure.

These issues have been taken up recently by Gilles Duranton (2007). Three facts about local growth and industrial change are the starting point of that paper. First, Duranton shows that there is considerable "churning” of industries across cities. Single industries grow or decline relatively quickly in cities and cause rapid changes of the local industry compositions over time. Second, entire cities move relatively slowly up or down the country's urban hierarchy. The speed at which some cities take over others in the distribution of total city sizes is low compared to the frequent changes in the location hierarchy for single industries. Finally, these processes occur within a distribution of city sizes that is stable over time. Duranton develops a theoretical framework - based on a spatial version of the quality-ladder endogenous growth model by Grossman and Helpman (1991) - that accommodates all three facts. Industries move across cities following endogenous cross-sector innovations. Cities experience gains and losses of industries, which partly offset each other, so that entire cities "churn” less than single industries, and urban growth goes along with industry turnover. Finally, the model generates a concave distribution of city sizes in the steady-state, where individual cities are mobile within the distribution due to the endogenous industrial relocations. Using US and French data, Duranton finds that this steady-state city size distribution of his model matches the actual distributions in these two countries quite closely, actually better than Zipf`s law.

\footnotetext{
${ }^{1}$ Theories of urban growth that generate such an equilibrium city size distribution include, e.g., Eaton and Eckstein (1997), Black and Henderson (1999), Gabaix (1999), Eeckhout (2004), Rossi-Hansberg and Wright (2007) or Cordoba (2008). A survey of that literature is provided by Gabaix and Ionannides (2004).
} 
The purpose of our paper is twofold. In a first step we use data on West German local industries (1977-2002) to study the robustness of Duranton's recent results. We also find considerable support for industry churning in Germany, even after controlling for structural change. When calibrating the model using our data, we obtain the result that the simulated city size distribution resembles the West German distribution very closely. The model is a much more accurate description than Zipf's law, and it even achieves a better fit for West Germany than for France or for the US.

The main aim of this paper is then to provide new insights about the determinants of churning and structural change in cities, which are the central mechanisms of the Duranton-model. We create an "excess churning index", which summarizes the strength of intra-city industry reallocations corrected for overall changes in total local employment. ${ }^{2}$ The larger the value of this index is, the more change in the local industry composition has occurred over time. We provide an empirical analysis on the determinants of industry turnover at the local level, as measured by the excess churning index, and we address the following questions: What are the characteristics of cities that have exhibited the most rapid change, and how are industry turnover and growth related on the local level?

This exercise is important for at least two reasons. First, little is known about the determinants of industry turnover in urban economics so far. Substantive empirical literatures have analyzed the performance of metropolitan areas or single industries, and addressed the question which local economic structure is most conducive to growth (e.g. Glaeser et al. 1992, 1995; Henderson et al. 1995; Simon 2004). But the equally important issues, which type of cities exhibit the most rapid overall change in their industrial structure over time, and how the intensity of industry turnover is related to long-run growth, have not been analyzed so far.

Second and even more important, we hope to inspire further theoretical work with our empirical results. Even though the model by Duranton matches several stylized facts very closely, it neglects other aspects of urban growth that have been emphasized elsewhere. In particular, it leaves aside human capital as an engine of growth, which is the central driving force, e.g., in Eaton and Eckstein (1997) and Black and Henderson (1999). Below we will analyze, among other things, if skilled cities with a large employment share of universitytrained workers exhibit more change over time than unskilled cities, e.g., because skilled Schumpeterian entrepreneurs speed up the process of creative destruction of old-fashioned local industry structures. Furthermore, industries in the Duranton-model are inherently symmetrical. Thus, there is no special role assigned to local specialization patterns, even

\footnotetext{
${ }^{2}$ Churning indices have been used before by labor economists (see Davis and Haltiwanger 1998), yet detached from any spatial or urban dimension of employment.
} 
though Simon (2004) convincingly argues that the initial structure is likely to influence a city's subsequent development. We will analyze if cities are more likely to change if they are initially specialized in certain industries, and if yes, in what type of industries.

To preview some of our results, we find that growth and churning are not notably correlated at the local level. Among the fastest growing cities, there are some that have strongly churned. Following Glaeser (2005), we see those as examples of "reinvention cities" which are successful because of rapid change ("reinvention”) of their industrial structure. Yet some other fast-growing cities have seen very little churning of their industries. Performing several estimations using different sub-samples of cities, we find that human capital is a key engine of growth and industrial change in successful cities, but not in declining ones. In the latter group industry turnover is strongly driven by the disappearance of old-fashioned and declining industries such as agriculture or mining. Taken together, our empirical findings suggest that the model by Duranton (2007) is a powerful description of the urban growth process. Still there are some aspects that are not captured by that model, but which are at the core of other theories of urban growth. In the light of our results, a combination of these different approaches seems to be a very promising agenda for further research.

The rest of this paper is organized as follows. In section 2 we briefly review the main features of the Duranton model, and simulate it using German data. Section 3 presents the empirical analysis on the determinants of local churning and growth. Section 4 concludes.

\section{2.) Brief Review and Replication of Duranton's approach}

\subsection{The Model}

Duranton (2007) embeds the quality-ladder growth model by Grossman and Helpman (1991) into an urban framework. The economy consists of a large (discrete) number of industries $(n)$, each producing a specific commodity of a certain quality at any point in time. Consumer preferences are symmetrical over the $n$ goods, and households only demand the brand with the best price-quality ratio from each industry. There is thus a unique quality leader in each industry, which is the only active firm that produces output. This quality leader holds a patent for its specific brand, which only expires when another firm innovates this industry and climbs up the next step on the quality ladder. The R\&D sector is competitive and features free entry. A research firm is specific to some industry $z$ and invests in R\&D. It innovates the own industry with some probability $\beta$, yet with some lower probability $\gamma<\beta$ the research effort targeted at industry $z$ actually leads to an innovation of some other industry $z^{\prime}$. This possibility of cross-sector innovations is crucial for the working of the model. 
A spatial structure is introduced by assuming that the economy is divided into $m$ cities, with $m<n$, across which the goods can be freely traded. It is assumed that research labs from industry $z$ must engage in R\&D in the same city where the active quality leader of industry $z$ is located, i.e., research is geographically tied to production. If a research lab happens to innovate a different industry, production of that sector moves (at no cost) from the previous location to the city of the successful innovator. The cross-sector innovations are, therefore, the mechanism by which industries move across cities and by which city sizes change over time. ${ }^{3}$ Since all industries are assumed to be symmetrical, and since the homogeneous workers can move freely across space, the size of some city $c$ can be identified by the number of active industries it hosts. Cities can gain or lose industries due to cross-sector innovations, but since these gains and losses partly offset each other, the model directly predicts that industries exhibit stronger churning than entire cities. City sizes change relatively slowly over time, whereas industries change their location fairly frequently in comparison.

Notice that larger cities are more likely to gain, but also to lose industries: More research labs are located in large cities that can successfully innovate and, thus, attract industries. At the same time, more local industries can be innovated from somewhere else. Hence, there will be stronger gross industry churning in large cities, but an important property of the model is that churning increases less than proportionately with city size. If a city already hosts many industries, it becomes less likely that the next innovation actually attracts a new industry, because the innovated sector is more likely to be already located there. ${ }^{4}$ Larger cities are more likely to lose an existing second-nature industry than to gain a new one, i.e., have a lower expected growth rate. The endogenous mechanisms of the model do, therefore, imply mean reversion across cities, and a city size distribution that is concave in the steady-state (see section 2.3. for further details).

\subsection{Stylized Facts}

Before continuing with a more formal analysis of the steady-state properties of the model, we present a few stylized facts in this sub-section which verify some of the model's basic predictions for the case of West Germany. Our data basis is the official employment statistics

\footnotetext{
${ }^{3}$ To prevent cities from disappearing, Duranton assume that each city hosts exactly one "first-nature industry" where production is always tied to that particular location In the event of a cross-sector innovation from somewhere else, the innovator must relocate (also at no cost) to the location of production. This is different in the remaining $(\mathrm{n}-\mathrm{m})$ "second-nature industries", where production moves in case of a successful cross-sector innovation from a different city. Only these "second-nature" industries drive changes in city sizes.

${ }^{4}$ The most extreme constellation is that all second-nature industries are concentrated in a single city at some point in time. In that case there is no industry left to be attracted from somewhere else. However, the "megacity" can still lose industries due to cross-sector innovations from one of the immobile "first nature" industries. This intuition applies more generally, and illustrates the concave relationship between city size and churning.
} 
of the Institute of Employment Research (IAB). This data set is a balanced spatial panel of local industries covering the time period 1977-2002. It encompasses all 326 Western German districts (=NUTS3 regions) except West Berlin, and 28 different industries representing the complete range of economic activities. ${ }^{5}$ Further details about the data set can be found in Appendix A.

First we compute the following raw churning index for every city $c=1, \ldots, 326$

$$
\text { Churn }_{c}=\frac{1}{25} \cdot\left(\sum_{t=1977}^{2001} \sum_{z=1}^{n} \frac{|e(z, c, t+1)-e(z, c, t)|}{e(c, t)}\right) \text {, }
$$

where $e(z, c, t)$ is the employment level of industry $z$ in city $c$ and at time $t$. This index measures the average gross industry turnover in city $c$ over the observation period $t=1977, \ldots, 2001 .^{6}$ This number can be compared to the yearly average aggregate change in each city’s total employment:

$$
\Delta E M P_{c}=\frac{1}{25} \cdot\left(\sum_{t=1977}^{2001} \frac{|e(c, t+1)-e(c, t)|}{e(c, t)}\right)
$$

There are exactly two cases when eqs. (1) and (2) are equal: Either all industries $z$ in city $c$ exhibit positive growth rates in a given time period, or all share a negative growth rate. Whenever some industries grow while others decline, there is faster industry turnover than aggregate change in city employment.

In fact, table 1 shows that, on average across the 326 West German cities, Churn ${ }_{c}$ is more than twice as large as $\triangle E M P_{c}$. I.e., the average city saw its industries changing twice the amount necessary to accommodate aggregate changes in employment. The average amount of raw churning, roughly 5\% p.a., is also decisively higher than the average structural change at the national level, as measured by $\triangle \operatorname{SecEMP}=(1 / T) \cdot \sum_{t=1}^{T} \sum_{z=1}^{n}(|e(z, t+1)-e(z, t)| / e(t))$, which is around $2.62 \%$ p.a.

These absolute numbers for West Germany are somewhat lower than for the US and for France as reported by Duranton, which is due to the fact that the industry classification in our

\footnotetext{
${ }^{5}$ It should be noted that our data set does not only include metropolitan, but also more rural areas. The West German districts are roughly comparable to US counties. In the remainder of this paper we will only use the term "city" for these administrative units.

${ }^{6}$ By construction this index is equivalent to an arithmetic mean of annual growth rates of all local industries $z=1, \ldots, 28$ in city $c$ over all time periods $t$ when growth rates are measured in absolute terms, and when the "change rates" of the single industries are weighted by the local employment shares of $z$ in period $t$, $e(z, c, t) / e(c, t)$.
} 
data set is not as disaggregated as in the US and French data, but in relative terms (Churn $_{c} / \triangle E M P_{c}$ ) we obtain numbers in the same ballpark. ${ }^{7}$

Table 1: Churning in Western Germany, USA and France

\begin{tabular}{|l|l|l|l|l|}
\hline & Churn $_{c}$ & $\Delta E M P_{c}$ & Churn $_{c} / \triangle E M P_{c}$ & $\Delta \operatorname{SecEMP}$ \\
\hline West Germany & $\mathbf{4 . 9 8} \%$ & $\mathbf{2 . 2 9} \%$ & $\mathbf{2 . 1 7}$ & $\mathbf{2 . 6 2} \%$ \\
\hline USA & $8.26 \%$ & $4.10 \%$ & 2.01 & $\sim 5 \%$ \\
\hline France & $11.40 \%$ & $5.20 \%$ & 2.19 & $\sim 5 \%$ \\
\hline
\end{tabular}

Source: Numbers for USA and France from Duranton (2007), numbers for Germany own calculation

The other two basic predictions from the model are that large cities churn more than small cities, but at a decreasing rate, and that there is mean reversion across cities. Both predictions can be addressed in a straightforward way. When regressing $\log \left(\right.$ Churn $\left._{c}\right)$ on the log of total city employment in the base year period $t_{0}=1977, \log e\left(c, t_{0}\right)$, we obtain a coefficient equal to -0.13 with standard error 0.01 (the French and US estimates are -0.20 and -0.21 , respectively). Since the churning index (1) is normalized by total city employment, these results suggest that churning increases less than proportionately with city size. Secondly, when regressing the long-run city employment growth rates over the period 1977-2002 on $\log e\left(c, t_{0}\right)$, we obtain a coefficient of -0.099 (std.error 0.015). This is consistent with the literature on mean reversion across cities (e.g., Glaeser et al., 1995) and also compares to the coefficient -0.11 for France as reported by Duranton. In sum, the basic stylized facts about industry churning and city growth for West Germany appear to be very similar as in the USA and in France.

\subsection{Simulation of the Steady-State City Size Distribution}

In this sub-section we describe the steady state city size distribution of Duranton's theoretical model, and we calibrate it using our data. Recall that cross-sector innovations of secondnature industries are the only way by which city sizes can change in the model. Let $i$ denote the number of industries a city hosts. This is a sufficient statistic to describe the city size, and $i=1$ is the minimum size due to the presence of the city-specific first-nature industries.

\footnotetext{
${ }^{7}$ To complement this analysis we have also performed a Markovian analysis of mean passage times for industries and cities. Consistent with Duranton's results we find that mean passage times to move from the lowest to a highest quartile in the respective location ranking are much faster for single industries than for entire cities. More detailed results on this point are available upon request from the authors.
} 
Furthermore, let $m_{i}$ be the number of cities of size $i$. In the steady state, the number of cities of any size $i$ must be constant over time. More formally, it is required that $E\left[m_{i}(t+d t)\right]-m_{i}(t)=0$ holds for any arbitrarily small time interval $d t$. Hence, the probability of having one more city of any size $i$ must be equal to the probability of having one less city of that size, conditional on the event of a cross-sector innovation.

This reasoning can be illustrated for the case of cities of size one $(i=1)$. The probability that $m_{1}$ increases is equivalent to the probability that a city of size $i=2$ loses its second-nature industry due to a cross-sector innovation from a research lab that is located in a city which has at least the size $i=2{ }^{8}$ There are $m_{2}$ cities of size $i=2$, and $\left(n-m_{1}-2\right)$ research labs that are neither located in cities of size one, or in the city that loses the industry itself. The number of all possible cross-sector innovations in the economy is given by $n(n-1)$. Hence, the conditional probability that $m_{1}$ increases can be expressed as $m_{2}\left(n-m_{1}-2\right) / n(n-1)$. In a similar vein, the conditional probability that $m_{1}$ decreases is equivalent to the probability that a research lab from a city of size $i=1$ successfully attracts an industry from a city that is strictly larger than $i=2: m_{1}\left(n-m-m_{2}\right) / n(n-1)$. In the steady state, these two conditional probabilities must be equal, i.e., the condition $m_{2}=\frac{n-m}{n-2} \cdot m_{1}$ must hold.

Generalizing this reasoning, Duranton shows that the steady state city size distribution of the model can be described in terms of the parameters $n$ and $m$ only. It is given by the following equation (see eq. 28 and the appendix of Duranton 2007):

$$
m_{i}=\frac{m(m-1)}{n-1} \cdot \prod_{j=1}^{m-2} \frac{n+1-m-i+j}{n-m+j},
$$

which is monotonically decreasing in $i$. That is, there are strictly more cities of size one than of size two $\left(m_{1}>m_{2}\right)$, more cities of size two than of size three $\left(m_{2}>m_{3}\right)$, etc. This in turn implies that larger cities are more likely to lose one of their existing industries than to gain an additional one.

We can readily use our empirical data on West German local industries to simulate the city size distribution that is generated by the model. The simulation procedure stays as close as possible to the original approach used by Duranton (2007) and is described in greater detail in

\footnotetext{
${ }^{8}$ If the second-nature industry from a city of size two gets innovated by a research lab from a city of size one, there would be no net increase in $\mathrm{m}_{1}$. The possibility that a city of size $\mathrm{i}=3$ loses two industries at the same time, etc., can be neglected since the time interval dt in which innovations occur can be made arbitrarily small.
} 
appendix B. In each run of one simulation, 10,000 cross-industrial innovations are randomly drawn. ${ }^{9}$ Each run yields one fictitious distribution of city sizes, after which cities are ranked by the natural log of their simulated size. We repeat this procedure 1,000 times and compute the average of the fictitious natural log size for each rank. This outcome, the simulated city size distribution, is then compared to the actual city size distribution of West Germany in the following fashion:

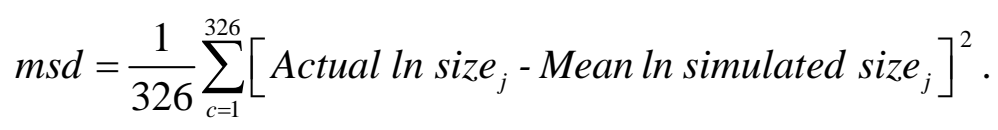

We construct the simple efficiency criterion $R^{2}=1-v a r / m s d$, where var is the variance of the actual (log) city sizes. This $R^{2}$-measure depicts how much of the sample's variation can be explained by the model.

Results are very encouraging. The $R^{2}$ of the benchmark model is 92\% for West Germany (the numbers for France and the US are 91\% and 85\%, repectively). To set these results into perspective, we have also constructed a Zipf counterfactual. We compute how the employment distribution across cities would look like if Zipf's law held perfectly, and compare this fictitious city size distribution to the actual one. ${ }^{10}$ The respective $R^{2}$ for the Zipf scenario is a meagre $23 \%$.

To further evaluate the model's performance we have plotted the actual rank-size distribution of West German cities, the rank-size relationship that is generated by the model, and the simple Zipf line with slope -1 in figure 1 . The concave relationship that is generated by the model fits the actual distribution in Germany fairly closely. In fact, the model performs even better for Germany than for France or for the US. Despite the lumpiness of industries (this is why the simulations look stepwise in the lower tail), the model still replicates the lower tail better and underestimates the size of the bigger cities with lower rank. The simulated ranksize curve moves even closer to the actual city size distribution when we introduce ad-hoc agglomeration effects in the $\mathrm{R} \& \mathrm{D}$ sector (see also appendix $\mathrm{B}$ ). This assumption implies relatively more successful innovations, and hence more industries that are attracted by large cities. The overall performance of the model increases to 0.922, and the fit in the upper tail is improved since large cities will be relatively larger the stronger the agglomeration effects are.

\footnotetext{
${ }^{9}$ We experimented with more simulated innovations, but in general 10,000 were sufficient for convergence. Additionally, we simulated a scenario where initially industries are uniformly distributed across cities. Similar results were obtained with one million innovations in each run.

${ }^{10}$ Two conditions must be met to compute the Zipf counterfactual: First, the ln rank-ln size relationship must hold perfectly, with the Zipf coefficient equal to -1 . Second, the sum of the implied city sizes must be equal to the sum of the real world city sizes. Given that there are 326 cities in the data set, there is precisely one city size distribution that satisfies both conditions.
} 


\section{Figure 1: Simulation results}

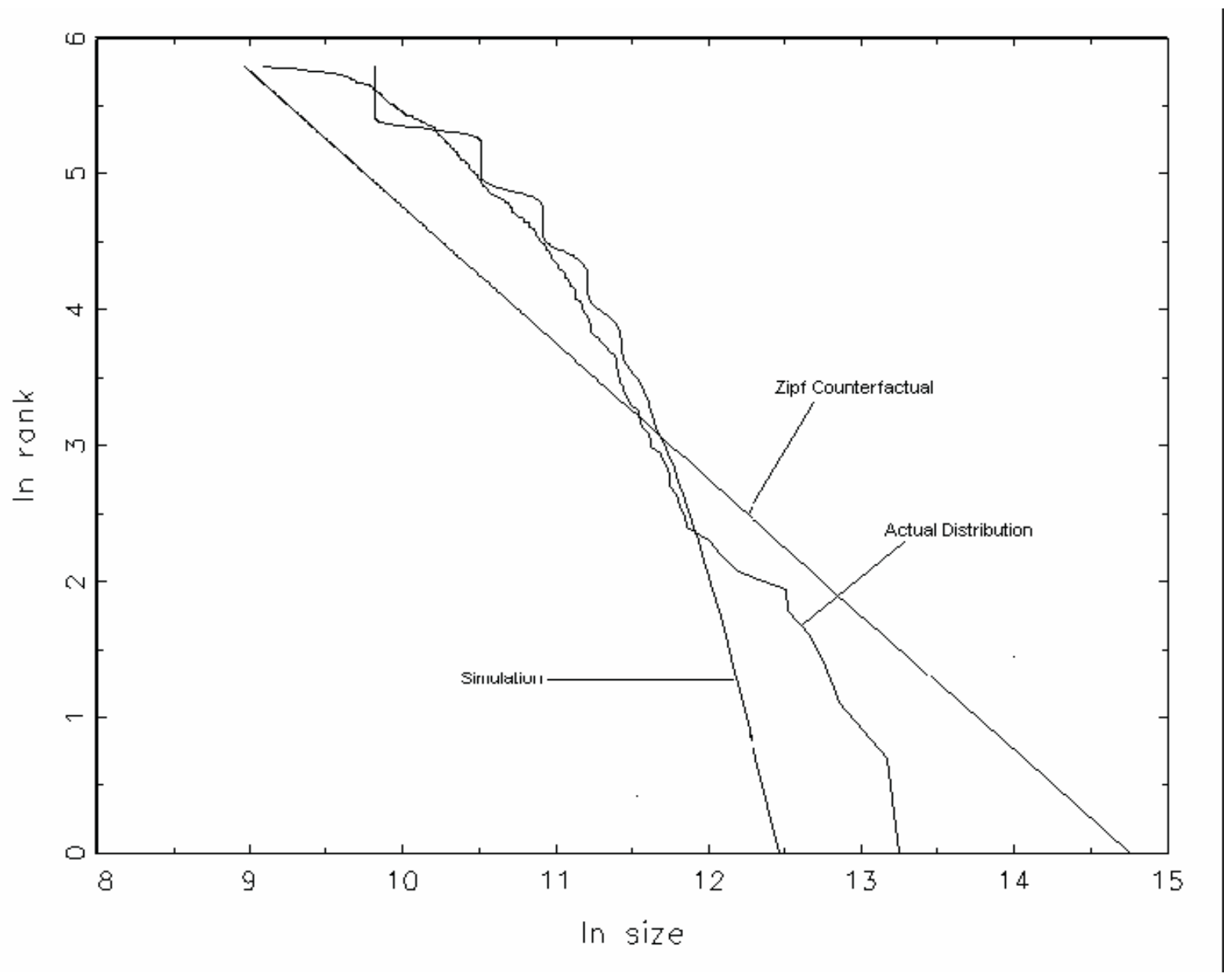

\section{3.) Empirical Analysis}

The previous section leads to the conclusion that the recent results by Duranton (2007) appear to be very robust. His model performs remarkably well in replicating the West German city size distribution, much better than Zipf's law. Since the basic mechanism of the model is the churning of industries across cities, it seems to be important to investigate further aspects related to this industry turnover. In the data we observe considerable variation in the churning indices across cities: The city with the strongest industry turnover has a churning rate around four times as large as the city with the least change in its industry composition. We also observe heterogeneity along several other dimensions: Some cities are considerably more skill-intensive than others; some cities are strongly specialized in particular industries whereas other cities have more balanced initial industry compositions, etc. Most of this heterogeneity refers to characteristics that are not directly part of the Duranton-model. For example, workers in the model are assumed to be homogenous, industries are assumed to be symmetrical, and cities are not inherently different. From an empirical point of view and as a direction for 
further theoretical extensions it is crucial, however, to understand if certain city characteristics are robustly related to churning patterns.

Two issues immediately come to mind. First, do "skilled cities" with a large local share of university-trained workers exhibit more rapid industry turnover than "unskilled cities”? This may be possibly due to the fact that the R\&D process that is needed to attract footloose second-nature industries is skill-intensive. Second, what is the role of the initial industry composition for subsequent churning and growth? Do cities with an idiosyncratic initial specialization pattern exhibit different turnover patterns than cities with an average initial industry mix? This issue appears to be quite complex. A city that is initially specialized in the "wrong” industries may be interested in changing considerably, whereas a high concentration of the "right" industries may be an indicator that this city is less likely to change in the future. In the empirical analysis in this section we will analyze, among other things, the effect of human capital and initial industry structure for subsequent city churning and city growth.

\subsection{Churning in Cities}

As the dependent variable we use the average annual excess churning rate of city $c=1, \ldots, 326$

$$
\begin{aligned}
\text { ExcChurn }_{c} & =\text { Churn }_{c}-\Delta E M P_{c} \\
& =\frac{1}{T} \cdot \sum_{t=1}^{T}\left[\frac{\left(\sum_{z=1}^{n}|e(s, c, t+1)-e(s, c, t)|\right)-|e(c, t+1)-e(c, t)|}{e(c, t)}\right] \times 100
\end{aligned}
$$

This index has a straightforward interpretation: The larger ExcChurn ${ }_{c}$ is, the more has the industrial composition changed over the years, in excess of the overall change in the city's total employment level. The index has some notable properties: It is positive by definition and equal to zero if all industries $z$ within the city exhibit growth rates with the same sign. Notice that ExcChurn $_{c}=0$ by no means requires uniform growth rates across industries in $c$, but only that all industries grow or all shrink. If some industries grow and others decline with respect to absolute employment, the index $\operatorname{ExcChurn}_{c}$ becomes strictly positive, and it is larger the stronger the industrial reallocation is. ${ }^{11}$

\footnotetext{
${ }^{11}$ Alternatively one could have used the ratio $\operatorname{Churn}_{d} \Delta E M P_{c}$, which has a similar interpretation. We have performed such regressions as well and obtained qualitatively very similar results as those reported below.
} 


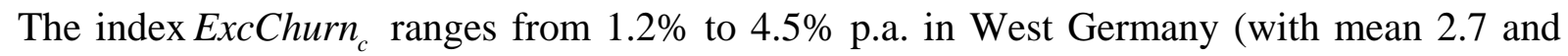
std.dev 0.6). A look at simple correlation tables reveals that ExcChurn ${ }_{c}$ is strongly negatively correlated with initial total city size in the base period $\mathrm{t}_{0}=1977(\rho=-0.6114)$.

Table 2: Determinants of Churning

\begin{tabular}{|c|c|c|c|c|c|c|}
\hline & $\begin{array}{c}\text { All cities } \\
\text { (1) }\end{array}$ & $\begin{array}{c}\text { All cities } \\
(2)\end{array}$ & $\begin{array}{c}\text { All cities } \\
\text { (3) }\end{array}$ & $\begin{array}{c}\text { All cities } \\
\text { (4) }\end{array}$ & $\begin{array}{l}\text { growing } \\
\text { cities } \\
\text { (5) }\end{array}$ & $\begin{array}{c}\text { declining } \\
\text { cities } \\
\text { (6) }\end{array}$ \\
\hline Total employment (log) & $\begin{array}{c}-\mathbf{0 . 5 0 6} * * * \\
(0.035)\end{array}$ & \begin{tabular}{|l}
$-\mathbf{~ 0 . 5 7 1}^{* * *}$ \\
$(0.044)$
\end{tabular} & $\begin{array}{l}-\mathbf{0 . 6 5 3} * * * \\
(0.06)\end{array}$ & $\begin{array}{l}-\mathbf{0 . 7 2 2 * * *} \\
(0.06)\end{array}$ & $\begin{array}{l}-\mathbf{0 . 7 3 1} * * * \\
(0.11)\end{array}$ & $\begin{array}{l}\mathbf{- 0 . 7 0 8 * * *} \\
(0.08)\end{array}$ \\
\hline $\begin{array}{l}\text { Share of workers with } \\
\text { University degree }\end{array}$ & -- & \begin{tabular}{|l}
$5.338^{* *}$ \\
$(2.24)$
\end{tabular} & $\begin{array}{c}3.169 \\
(3.23)\end{array}$ & $\begin{array}{r}-1.721 \\
(2.80)\end{array}$ & $\begin{array}{l}2.383 \\
(4.83)\end{array}$ & $\begin{array}{r}-7.300 \\
(4.48)\end{array}$ \\
\hline $\begin{array}{l}\text { Share of workers with } \\
\text { completed apprenticeship }\end{array}$ & -- & -- & $\begin{array}{r}-0.902 \\
(0.68)\end{array}$ & $\begin{array}{r}-0.878 \\
(0.75)\end{array}$ & $\begin{array}{r}-1.865 \\
(1.19)\end{array}$ & $\begin{array}{r}-0.036 \\
(0.97)\end{array}$ \\
\hline $\begin{array}{l}\text { Share of workers in large } \\
\text { plants (>100 emp) }\end{array}$ & -- & -- & \begin{tabular}{|c|}
-0.098 \\
$(0.60)$
\end{tabular} & $\begin{array}{c}-0.242 \\
(0.93)\end{array}$ & $\begin{array}{r}-0.034 \\
(1.43)\end{array}$ & $\begin{array}{c}-1.128 \\
(1.38)\end{array}$ \\
\hline $\begin{array}{l}\text { Share in medium-sized } \\
\text { plants }(20-100 \text { emp })\end{array}$ & -- & -- & $\begin{array}{l}-2.776^{* *} \\
(1.30)\end{array}$ & $\begin{array}{l}-4.903^{* * *} \\
(1.58)\end{array}$ & $\begin{array}{l}-4.860^{* *} \\
(2.24)\end{array}$ & $\begin{array}{l}-6.269 * * \\
(2.41)\end{array}$ \\
\hline Average age employees & -- & -- & $\begin{array}{r}-0.018 \\
(0.04)\end{array}$ & $\begin{array}{r}-0.009 \\
(0.03)\end{array}$ & $\begin{array}{l}0.036 \\
(0.07)\end{array}$ & $\begin{array}{c}-0.063 \\
(0.05)\end{array}$ \\
\hline Fraction on male employees & -- & -- & $\begin{array}{l}0.732 \\
(0.88)\end{array}$ & $\begin{array}{l}-2.899 * * \\
(1.12)\end{array}$ & $\begin{array}{r}-1.847 \\
(1.75)\end{array}$ & $\begin{array}{l}-3.697 * * \\
(1.62)\end{array}$ \\
\hline Average daily wage (log) & -- & -- & $\begin{array}{l}0.204 \\
(0.84)\end{array}$ & $\begin{array}{l}1.379 \\
(0.88)\end{array}$ & $\begin{array}{r}-1.646 \\
(1.47)\end{array}$ & $\begin{array}{l}3.125^{* *} \\
(1.35)\end{array}$ \\
\hline $\begin{array}{l}\text { employment share } \\
\text { agriculture }\end{array}$ & -- & -- & -- & $\begin{array}{l}11.96^{* * *} \\
(4.66)\end{array}$ & $\begin{array}{l}9.05 \\
(5.74)\end{array}$ & $\begin{array}{l}13.49 * \\
(7.68)\end{array}$ \\
\hline $\begin{array}{l}\text { employment share } \\
\text { metallic mining }\end{array}$ & -- & -- & -- & $\begin{array}{l}4.33^{* * *} \\
(1.01)\end{array}$ & $\begin{array}{l}1.26 \\
(1.55)\end{array}$ & $\begin{array}{l}6.53 * * * \\
(1.35)\end{array}$ \\
\hline $\begin{array}{l}\text { employment share } \\
\text { non-metallic mineral mining }\end{array}$ & -- & -- & -- & $\begin{array}{l}5.42 * * * \\
(1.76)\end{array}$ & $\begin{array}{l}3.12 \\
(2.66)\end{array}$ & $\begin{array}{l}4.23 * \\
(2.78)\end{array}$ \\
\hline Constant & $\begin{array}{l}7.976^{* * *} \\
(0.371)\end{array}$ & $\begin{array}{l}8.515^{* * *} \\
(0.436)\end{array}$ & $\begin{array}{l}10.04^{* * *} \\
(2.93)\end{array}$ & $\begin{array}{l}8.469^{* * *} \\
(3.64)\end{array}$ & $\begin{array}{l}20.68 * * * \\
(6.42)\end{array}$ & $\begin{array}{l}3.241 \\
(5.52)\end{array}$ \\
\hline NOBS & 326 & 326 & 326 & 326 & 142 & 184 \\
\hline $\mathrm{R}^{2}$ & 0.3740 & 0.3881 & 0.4384 & 0.6222 & 0.7189 & 0.6417 \\
\hline
\end{tabular}

When running a simple bi-variate OLS regression, as reported in column 1 of table 2, we find that (log) total employment in $\mathrm{t}_{0}$ is highly significant and explains nearly $40 \%$ of the variation of excess churning rates. This high explanatory power is reassuring of the theoretical model, which precisely predicts such a negative relationship between city size and industry 
churning. ${ }^{12}$ Starting from this benchmark specification, we have performed several regressions to find out which characteristics are robustly related to excess churning rates. All controls are measured for the base year period $t_{0}=1977$. Of particular interest are skill-related variables, as well as variables that describe the initial industry composition of the cities.

The first basic conclusion that we draw is that human capital does not have an obvious and robust effect on churning patters. When we only include the local share of high-skilled workers in the regression (see second column), we do in fact find a positive and significant effect on city churning. This result is not robust, however. Controlling for further city characteristics with which human capital is likely to be correlated, such as the share off workers in large firms, it turns out that the positive impact of high-skilled workers on churning is no longer significant (see third column). This indicates that the specification in the second column suffers from a basic OV bias. When looking at the full sample we find that "skilled cities" with a large employment share of university-educated workers did not exhibit notably stronger industry turnover than "unskilled cities” over time. We will come back to the role of human capital below when we present more detailed results for different sub-samples of cities.

Further controls included in the third column, such as the age and gender structure or the average city wage, do not seem to play a role either. The only characteristic that is related to churning patterns is the regional firm-size composition. Cities face less churning if a large share of the employees work in medium-sized firms (with 20-100 employees), which suggests that the location of such firm types is relatively stable. All in all, it turns out that total city size remains the only highly significant explanatory variable. The other characteristics do not add much to the understanding of excess churning rates. The regression $\mathrm{R}^{2}$ increases only mildly from the first to the third specification.

As the next step we add variables that describe the cities' initial industry composition. More precisely, we add the initial local employment shares of 27 industries, leaving the public sector as the excluded reference category. For expositional purposes we only report some selected results in the fourth column of table 2, leaving the complete results tables for appendix C. The most important insight here is that cities with a large initial employment share in agriculture and (metallic and non-metallic) mining have experienced significantly

12 This property can be seen even more clearly when re-estimating the first specification as follows: Churn $_{c}=7.62+1.092 \Delta E M P_{c}-0.49 \log \left(e m p_{c, t o}\right)$, where all estimated coefficients are highly significant. The coefficient on $\triangle E M P_{c}$, which is larger than one, is also consistent with the property of the theoretical model that industries churn more than entire cities. 
stronger industry turnover. ${ }^{13}$ This points at an important dimension of churning: Consider a city that is initially specialized in industries such as agriculture or mining, which tend to be old-fashioned and declining industries in developed countries like Germany. Such a city is likely to be interested in launching a process of industrial change, in order to cope with its legacy of a disadvantageous economic structure. In effect, that city is likely to change notably over time, but it will not necessarily grow fast because of the high initial concentration of declining industries. Our results actually suggest that excess churning can be driven by the fact that cities have to deal with their initial structural problems.

We run the same specification on the two sub-samples of growing and declining cities with above-average and below-average total employment growth rates over the period 1977-2002, respectively. Results are reported in the $5^{\text {th }}$ and $6^{\text {th }}$ column of table 2 and in appendix $C$ (columns 3 and 5). We find that the positive effect of the initial agriculture or mining share on excess churning is driven by the declining cities. Among the growing cities a high concentration of certain industries (like optics and the IT-sector) leads to less subsequent churning, i.e., cities specialized in these fairly modern sectors are less likely to change afterwards. Yet, there is no notable impact of agriculture or mining on churning patterns in this group of regions. Among the declining cities we find a significantly positive effect of these initial industry shares.

We have also addressed the robustness of this result by running a regression using the full sample of cities, where we include the initial industry shares and interaction terms of these shares with a dummy variable that indicates whether the city is a growing or a declining one (not shown). Consistent with the results reported above, we obtain significantly positive coefficients of the agriculture and mining share on city churning and negative interaction terms. These findings verify that churning is driven by the disappearance of old-fashioned industries, yet only among declining cities.

\subsection{Churning versus Growth: A Classification of Four Different Types of Cities}

An obvious and crucial question is how city churning and city growth are interrelated. In figure 2 we depict long-run city growth rates on the horizontal, and excess churning rates on the vertical axis, both measured relative to the average West German city. Regions to the left (right) of the vertical solid line have grown faster (slower) than the West German average over the years 1977-2002. Regions above (below) the horizontal line have churned more (less) than the average region over the same time period.

\footnotetext{
${ }^{13}$ There are only two additional significant coefficients for the other initial industry shares when looking at the full sample of regions (gastronomy and health care, see column 1 of appendix C).
} 
Figure 2: City Growth and Industry Churning

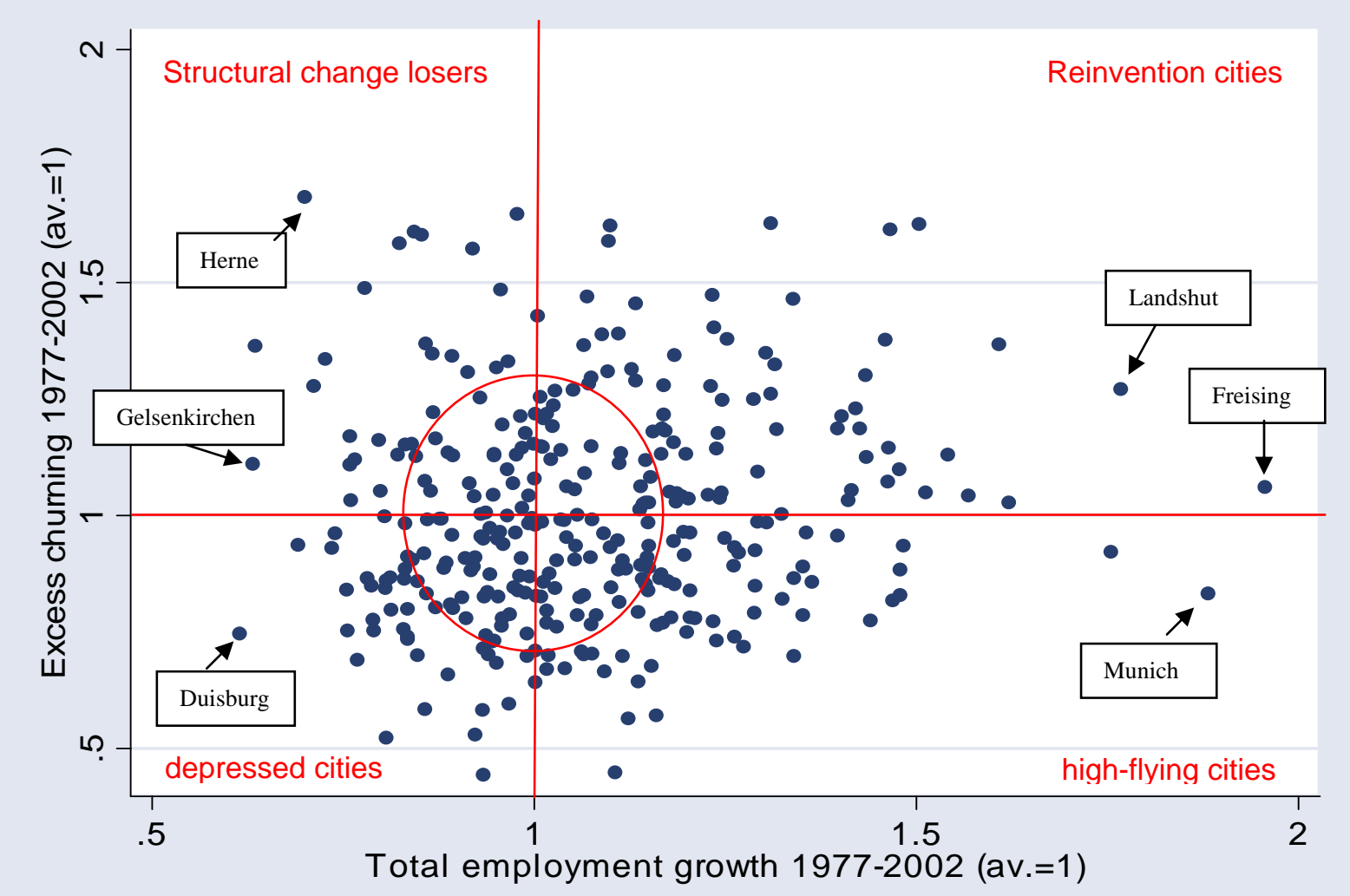

Figure 2 shows no clear correlation between growth and excess churning ( $\rho \approx 0.1$ ). In some cities, located in the north-east corner of the figure, high growth rates coincide with very active industry turnover. Yet other growing cities, located in the south-east corner, have churned relatively little. A similar distinction can be made for the group of declining regions. Those in the north-west corner exhibit above-average excess churning rates, whereas those in the south-west corner rank below the average both with respect to growth and churning.

Following Glaeser (2005), we think of the regions in the north-east corner as examples of successful "reinvention cities". The above-average values of the growth rate and the ExcChurn $_{c}$-index imply that these regions have seen considerable industry turnover, such that the employment losses in the declining sectors were more than compensated by the gains in the growing industries. Reinvention cities in West Germany are often relatively small cities, many of them located in the state of Bavaria (like Freising or Landshut), which was dominated by traditional industries but then developed rapidly over the 1970s and 1980s to become of one of Germany's leading high-tech states. The success of these regions coincides with rapid change, which suggests that the success of these cities may be due to the fact that they have "re-invented" themselves fairly quickly. 
Yet, there is also a huge group of regions where high growth coincides with relatively low excess churning rates. A coincidence of strong growth and low excess churning indicates that, by and large, all local industries have exhibited positive growth rates. The best example of such a city is Munich. Of course, even in Munich some industries grew stronger than others. Hence, relative industry shares have changed over time, but very few industries actually shrank in absolute terms. In view of this, we call the cities in the south-east corner of the figure the "high-flying cities" which generally grow without exhibiting strong industrial change.

As for the declining cities, those in the north-west corner still have above-average excess churning rates. At least some industries have grown in these cities, even though this growth was not sufficient to compensate the employment losses of the declining sectors. Many large cities from the coal\&steel dominated Ruhr area (like Herne, Gelsenkirchen, Dortmund) belong to this group. These cities launched a process of structural change, but what has been achieved was not sufficient to compensate the losses in the declining traditional sectors. We therefore call these regions the "structural change losers". Finally there are some cities, where most industries shrank over time, so that low city growth coincides with a low excess churning rate. We call these regions in the south-west corner the "depressed cities", since encouraging experiences of at least some growing industries appear to be absent.

Looking at some descriptive facts about the four different types of cities, one finds that reinvention cities are less dense, less human capital intensive and more agricultural than highflying cities. The high-flyers were initially stronger specialized in modern manufacturing industries. In comparison of the two types of declining cities, the structural change losers have on average a much larger initial employment share in the mining industry.

\subsection{Churning and Growth in Different Types of Cities}

In this section we present several regressions on the determinants of churning and city growth for the different types of cities. The selection of a city into one of the sub-samples (reinvention cities, high-flyers, structural change losers, depressed cities) is of course not random. However, our aim in this paper is not to uncover causal mechanisms that determine the success of cities ex ante, but we try to develop new stylized facts about the processes of industry turnover and growth ex post: What have been the main characteristics of the cities in the four respective groups that are notably correlated with their growth performance and their turnover pattern? 
Table 3 highlights the most important results. In general, we have used the same specification as in the $4^{\text {th }}-6^{\text {th }}$ column of table 2 on different sub-samples of cities. ${ }^{14}$ Furthermore, we have run all regressions not only with $\operatorname{ExcChurn}_{c}$ as the dependent variable, but also with the standard long-run employment growth rate of cities over the period 1977-2002.

\section{[TABLE 3 HERE]}

In the first column of table 3 we present the results for excess churning and growth using the full sample of cities (regressions 1 and 2). The share of university-educated workers is insignificant in the estimation of the excess churning rate, as argued above. Yet, it is positive and highly significant in the standard employment growth regression. The important role of human capital as an engine of local growth is well documented in several previous studies that find that "skilled cities" exhibit faster employment/population growth than unskilled cities (see Simon 1998, Glaeser and Saiz 2004 for the US, Suedekum 2006 for West Germany). We obtain consistent results. However, on average there is no evidence that the faster growth of skilled cities is accompanied by more industrial change.

Yet, a more detailed picture emerges when repeating the regressions for the group of growing cities only, and for the two sub-groups of growing cities (specifications 3-8). First of all we find that human capital is an even stronger engine of city growth within growing cities than in the full sample (compare specifications 2 and 4), yet the impact is again even larger among the fast growing and quickly changing "reinvention cities". Among those cities which grow and churn, the skill-intensive ones grow much faster although they are not the ones that exhibit the fastest turnover within the group of fast churners.

Interestingly, when looking at the "high-flying cities" which grow fast but churn relatively little, the results about the impact of human capital are reversed. Within this group we find that the skill-intensive cities have not grown faster, but instead they have exhibited a somewhat stronger turnover. Furthermore, the impact of the initial industry composition on subsequent growth seems to be quite different between the two types of growing regions (see in particular appendix C, columns 8 and 10). For both, the re-invention and the high-flying cities, we find no significant impact of the initial mining or agricultural employment share on the strength of the subsequent excess churning or growth. Yet, growth among the high-flying cities was notably positively correlated with the initial employment shares of several

\footnotetext{
${ }^{14}$ Some coefficients are omitted in table 3 for expositional purposes. The complete set of results is reported in appendix C.
} 
industries (e.g., education or automobile production), whereas the initial industry composition played a much lesser role for growth among the reinvention cities.

These findings suggest that the most skill-intensive "reinvention” cities apparently manage to accommodate the rapid industrial change with particularly strong growth of the rising industries. These cities must exhibit declining employment in a notable number of industries, since otherwise they would not belong to the group of above-average churners. This decline is dominated by the growth of rising industries, however, and this type of growth appears to be strongly human-capital driven. This finding is nicely consistent with Glaeser's study on Boston (see Glaeser 2005), where he argues that the city’s success in “reinventing itself” was essentially due to its human capital. At the same time, the lack of correlation between the initial industrial structure and growth suggests that the reinvention cities did not have strongly idiosyncratic industrial structures that caused growth. Within this group of regions, human capital actually seems to be the principal engine of growth.

Growth among the "high-flying" cities, on the other hand, was not significantly driven by human capital. We believe that this result is due to the fact that the group of "high-flyers" entails some successful cities, where growth is due to fortunate circumstances such as location or market potential, which are mostly detached from skill intensity. Furthermore, these cities have been specialized in the "right" industries already in the beginning of the observation period, as suggested by the positive effects of several industry shares on growth (see appendix C). These cities have been, in a sense, lucky enough to experience a growth process that was not strongly driven by human capital, and that also did not require the city to change constantly. Yet, within this group of cities with above-average growth and below-average churning we still find that the most skill intensive ones show the relatively most rapid industry turnover. This also suggests an important role for human capital. The most skilled "high-flyers" may realize that a process of active industrial change complements the generally fortunate development that is common to the cities that belong to this group.

In declining cities, churning and growth seems to have quite different characteristics. Most importantly, we find no significant effect of human capital, neither on churning nor on growth. This is true for the group of declining regions in general, but also for the twosubgroups of declining regions with above-average and below-average industry turnover, respectively. This suggests that the effect of human capital as a catalyst of local growth and change operates within the group of successful cities. Within the group of unsuccessful cities we do not find that the skill-intensive ones are relatively less unsuccessful. What stands out for the group of declining regions is the effect of the initial agriculture and mining share. 
Among the declining cities we find that those with large initial shares in agriculture and mining have churned stronger, but grew less over the years. I.e., these regions have been losing employment in the declining industries, but have not compensated this decline with growth in other sectors. Industries other than mining or agriculture show no significant correlation with churning among the declining regions, which points at the special role of these two sectors for the declining cities.

To sum up, human capital is the key driver of growth and change in successful cities. In strongly changing "reinvention cities" human capital particularly boosts the growth of the rising industries, and it accelerates industry turnover in the generally fast-growing "highflyer” cities. In declining cities, however, human capital does not appear to play an important role as a cushion for the local development. Human capital neither fosters the growth performance, nor does it lead to stronger turnover in these cities. The story of industry turnover in declining cities appears to be a story of coping with initial structural problems, i.e., the disappearance of old-fashioned declining industries.

\section{4.) Conclusions and Outlook}

In this paper we have shown that the recent model by Duranton (2007) is successful in explaining a variety of facts about industry turnover and growth in West German cities and local industries. The steady-state city size distribution of that model comes very close to the actual distribution, and the model clearly outperforms Zipf's law. These results are reassuring of the importance of Duranton's approach, since all essential results can be confirmed for the case of West Germany in our independent study. Secondly, we have established several new facts and insights about industrial churning in cities, which is the central mechanism of that model. In particular, we have investigated the effect of human capital and the initial industry composition on industry turnover in different types of cities.

Our empirical findings point at some aspects of the urban growth process that are not fully captured by the Duranton-model. The prominent role of the skill structure for local growth among successful cities is strongly in line with theories in the spirit of Black and Henderson (1999), which relies on human capital accumulation as the main growth engine. Worker heterogeneity is neglected as an integral part of Duranton (2007), however. Urban growth appears to carry facets of both theories. Both, industry reallocations and human capital play important roles in reality. It seems to be an exciting area for further research to combine these two views of the urban growth process in a unifying framework, possibly by being more 
explicit about the role of human capital for the endogenous R\&D process that drives industry turnover.

A second feature that is not captured by Duranton (2007) concerns the fact that the development of cities sometimes cannot be detached from long-run trends of structural change. Following Duranton we consistently find strong spatial mobility of industries in general, which causes rapid industry turnover at the local level in West Germany. Yet, the evidence also suggests that not all cities and industries are symmetrical in this respect. At least for some cases we find fairly persistent local specialization patterns in the data, so that the fate of a city is closely tied to the fate of a particular sector. Some sectors, such as agriculture and mining, are on a long-term trend of decline. Cities with a high concentration of those sectors are stuck with a structural problem, which is resolved only slowly over time. Consistent with this view, we find that a large initial employment share of agriculture and mining is associated with more rapid subsequent industry turnover but with lower growth. Coming to grips with these observations will probably require including aspects of inertia in local economic structures as well as industry-specific growth trends into the model.

\section{References}

Black, D. and V. Henderson (1999), “A Theory of Urban Growth”, Journal of Political Economy 107: 252-284.

Córdoba, J.-C. (2008), “On the distribution of city sizes”, forthcoming: Journal of Urban Economics

Davis, S. and J. Haltiwanger (1998), "Measuring Gross Worker Flows”, in: J. Haltiwanger, M. Manser and R. Topel (eds.), Labor Statistics Measurement Issues, Chicago: University of Chicago Press, pages 77-119.

Duranton, G. (2007), "Urban Evolutions: The Fast, the Slow, and the Still", American Economic Review 97: 197-221.

Eaton, J. and Z. Eckstein (1997), "Cities and Growth: Theory and Evidence from France and Japan”, Regional Science and Urban Economics 27: 443-474.

Eeckhout, J. (2004), “Gibrat’s Law for (All) Cities”, American Economic Review 94: 14291451.

Gabaix, X. and Y. Ioannides (2004), "The Evolution of City Size Distributions," in: V.J. Henderson and J.-F. Thisse (eds.), Handbook of Regional and Urban Economics, Volume 4, Amsterdam: Elsevier-North Holland, pages 2341-2378.

Gabaix, X. (1999), “Zipf’s Law for Cities: An Explanation”, Quarterly Journal of Economics 114: 739-767. 
Glaeser, E. (2005), “Reinventing Boston: 1640-2003,” Journal of Economic Geography 5: 119-153.

Glaeser, E. and A. Saiz (2004), “The Rise of the Skilled City”, Brooking-Warton Papers on Urban Affairs 5: 47-94

Glaeser, E., J. Scheinkman and A. Shleifer (1995), "Economic Growth in a Cross-Section of Cities", Journal of Monetary Economics 36: 117-143

Glaeser, E., H. Kallal, J. Scheinkman and A. Shleifer (1992), “Growth in Cities”, Journal of Political Economy 100: 1126-1152

Grossman, G. and E. Helpman (1991), "Quality Ladders in the Theory of Growth", Review of Economic Studies 58: 43-61.

Henderson, V., A. Kuncoro and M. Turner (1995), "Industrial Development in Cities", Journal of Political Economy 103: 1067- 1090.

Rossi-Hansberg, E. and M. Wright (2007), “Urban Structure and Growth”, Review of Economic Studies 74: 597-624.

Simon, C. (2004), “Industrial Reallocation across US Cities 1977-1997”, Journal of Urban Economics 56: 119-143

Simon, C. (1998), "Human Capital and Metropolitan Employment Growth”, Journal of Urban Economics 43: 223-243

Suedekum, J. (2006), “Convergence of Human Capital Shares across Cities”, mimeo, University of Konstanz. 


\section{Appendices}

\section{Appendix A: Details about data set}

The data is a balanced spatial panel, with annual observations for the time period 1977-2002. Data is not subject to any censoring. For each local industry and year the following information is available:

- SIZE: the total employment level of full-time employees ( $\geq 35$ working hours per week) referring to workplace location

- $\quad$ MEDIUM, LARGE: the employment shares in medium-sized (20-99) and large (>100) establishments. Residual share is employed in small establishments ( $<20$ workers).

- HQ, MQ: employment share of workers with completed tertiary education, respectively with completed apprenticeship. Residual share: Workers without formal vocational qualification.

- AGE: average age of all employees in the respective local industry

- $M E N$ : fraction of men among all employees in the respective local industry

- WAGE: the average wage income per employee per calendar day, including all bonuses and extra payments subject to social security.

The 28 different industries that are distinguished in the data set are: Agriculture, Mining, Electronics, Chemical Industry, Synthetic Material, Non-metallic Mineral Mining, Glass \& Ceramics, Primary Metal Manufacturing, Machinery, Automobile, Office Supplies \& IT, Toys \& Jewellery, Wood-working, Paper \& Printing, Leather \& Textile, Food \& Tobacco, Building \& Construction, Transportation, Banking \& Insurance, Hotels \& Gastronomy, Health Care, Business-Related Services, Education, Leisure-Related Services, HouseholdRelated Services, Social Services, Commerce and the public sector. Data for the public sector contains only public employees with social security contributions but no civil servants, who are exempted from the social security system.

The abbreviations of variable names and the classification number of the industries refer to the full results tables presented in appendix C.

\section{Appendix B: Simulation of the steady state city size distribution}

The number of cities in the simulations is equal to the number cites in our dataset, hence $m=326$. The derivation of $n$ relies on the assumptions that all industries are homogenous in size, and that the smallest cities in our model host one industry. The number of the smallest cities can be shown to be

$$
m_{1}=\frac{m(m-1)}{(n-1)},
$$

see Duranton's appendix A, eq. (A12). Since $m_{1}$ cities host one industry, it must hold that the average size of the $m_{1}$ cities times $n$ must equal the sum of all employed people in the economy, defined as POP:

$$
P O P=\frac{1}{m_{1}} \cdot \sum_{c=1}^{m_{1}} e(c, t) \cdot n
$$


Solving (B1) for $n$ and inserting this into (B2) with $\mathrm{m}=326$ yields:

$$
P O P=\frac{1}{m_{1}} \cdot \sum_{c=1}^{m_{1}} e(c, t)+\frac{326(326-1)}{\left(m_{1}\right)^{2}} \cdot \sum_{c=1}^{m_{1}} e(c, t)
$$

Using the most recent year in our panel $t=2002$, we have $P O P \approx 16.28 \mathrm{~m}$. Then the best "fit" for equation (A3) is achieved with a value of $m_{1}=115$, which in turn implies a fixed industry size of approximately 18,400 employees and $n=885$ industries. These industries are then assigned to the 326 cities in proportion to their relative size in 2002.

In the first step of each simulation, one "innovator" of the $n=885$ industries is randomly picked from a discrete uniform distribution. The "innovated"' industry is then drawn from the remaining pool of $n-m=559$ second-nature industries. The "innovated" industry moves to the city of the "innovator"(or stays if already located there).

In the benchmark model every city faces a probability of being home to an "innovator" of $i_{c} / n$, where $i_{c}$ denotes the number of industries in city c. In an extension, we also consider ad-hoc agglomeration benefits to R\&D (yet, not in production) in the simulations. This is done by assuming that the probability for a city to innovate increases to $i_{c}^{1+\varphi} / n$, where $\varphi \geq 0$ captures the scale economies in R\&D. Like Duranton (2007) we allow $\varphi$ to vary over the 0.00-0.05 range in different simulations. Figure 1 above refers to the set of simulations with $\varphi=0.01$. 
TABLE 3: Growth versus churning - growing vs. declining cities (selected results)

\begin{tabular}{|c|c|c|c|c|c|c|c|c|}
\hline & \multicolumn{2}{|l|}{ ALL CITIES } & \multicolumn{2}{|c|}{ ALL GROWING CITIES } & \multicolumn{2}{|c|}{ RE-INVENTION CITIES } & \multicolumn{2}{|c|}{ HIGH-FLYERS } \\
\hline & Churning(1) & Growth (2) & Churning(3) & Growth(4) & Churning(5) & Growth(6) & Churning(7) & Growth(8) \\
\hline $\begin{array}{l}\text { Total employment } \\
\text { (log) }\end{array}$ & $\begin{array}{l}-0.722 * * * \\
(0.06)\end{array}$ & $\begin{array}{l}0.014 \\
(0.02) \\
\end{array}$ & $\begin{array}{l}-0.731 \text { *** } \\
(0.12)\end{array}$ & $\begin{array}{l}-0.084 * * * \\
(0.03) \\
\end{array}$ & $\begin{array}{l}-0.495 * * \\
(0.22) \\
\end{array}$ & $\begin{array}{c}-0.076 \\
(0.07) \\
\end{array}$ & $\begin{array}{l}-0.413 \text { *** } \\
(0.15)\end{array}$ & $\begin{array}{l}-0.133^{* *} \\
(0.06)\end{array}$ \\
\hline $\begin{array}{l}\text { share highly- } \\
\text { qualified workers }\end{array}$ & $\begin{array}{c}1.721 \\
(2.80) \\
\end{array}$ & $\begin{array}{l}.513 * * * \\
(1.61)\end{array}$ & $\begin{array}{c}-2.383 \\
(4.83) \\
\end{array}$ & $\begin{array}{l}6.015 \text { *** } \\
(2.47) \\
\end{array}$ & $\begin{array}{c}-14.341 \\
(17.22) \\
\end{array}$ & $\begin{array}{l}21.218 * * * \\
(5.76) \\
\end{array}$ & $\begin{array}{l}11.018 * * \\
(4.45)\end{array}$ & $\begin{array}{l}3.100 \\
(2.92)\end{array}$ \\
\hline Agriculture & $\begin{array}{l}11.965 * * \\
(4.66)\end{array}$ & $\begin{array}{l}-2.339 * * \\
(1.13)\end{array}$ & $\begin{array}{l}9.058 \\
(5.47) \\
\end{array}$ & $\begin{array}{c}-0.120 \\
(2.32) \\
\end{array}$ & $\begin{array}{c}-12.415 \\
(8.54) \\
\end{array}$ & $\begin{array}{l}2.528 \\
(2.98)\end{array}$ & $\begin{array}{l}-0.001 \\
(5.57)\end{array}$ & $\begin{array}{l}-1.342 \\
(2.37) \\
\end{array}$ \\
\hline Mining & $\begin{array}{l}4.337 * * * \\
(1.01)\end{array}$ & $\begin{array}{l}0.189 \\
(0.39) \\
\end{array}$ & $\begin{array}{l}1.265 \\
(1.55) \\
\end{array}$ & $\begin{array}{l}1.320 \text { ** } \\
(0.63)\end{array}$ & $\begin{array}{l}0.856 \\
(2.41) \\
\end{array}$ & $\begin{array}{l}1.207 \\
(0.79) \\
\end{array}$ & $\begin{array}{l}-5.224 \\
(4.62) \\
\end{array}$ & $\begin{array}{l}2.846 \\
(2.37) \\
\end{array}$ \\
\hline Constant & $\begin{array}{l}8.469 \text { ** } \\
(3.64)\end{array}$ & $\begin{array}{l}2.942 * * * \\
(1.10)\end{array}$ & $\begin{array}{l}20.688 \text { *** } \\
(6.42)\end{array}$ & $\begin{array}{l}0.250 \\
(1.82)\end{array}$ & $\begin{array}{l}13.258 \\
(10.45)\end{array}$ & $\begin{array}{l}4.617 \\
(3.53)\end{array}$ & $\begin{array}{l}12.868 * \\
(7.72)\end{array}$ & $\begin{array}{l}1.297 \\
(2.79)\end{array}$ \\
\hline NOBS & 326 & 326 & 142 & 142 & 73 & 73 & 69 & 69 \\
\hline $\mathrm{R}^{2}$ & 0.6222 & 0.6387 & 0.7189 & 0.5105 & 0.6039 & 0.7306 & 0.6849 & 0.7804 \\
\hline
\end{tabular}

\begin{tabular}{|c|c|c|c|c|c|c|c|c|}
\hline & \multicolumn{2}{|l|}{--} & \multicolumn{2}{|c|}{ ALL DECLINING CITIES } & \multicolumn{2}{|c|}{ STRUC. CHANGE LOSER } & \multicolumn{2}{|c|}{ DEPRESSED CITIES } \\
\hline & -- & -- & Churning(9) & Growth (10) & Churning(11) & Growth (12) & Churning(13) & Growth(14) \\
\hline $\begin{array}{l}\text { Total employment } \\
\text { (log) }\end{array}$ & -- & -- & $\begin{array}{l}-0.708 * * * \\
(0.08)\end{array}$ & $\begin{array}{l}0.027 * * \\
(0.01)\end{array}$ & $\begin{array}{l}-0.857 * * * \\
(0.16)\end{array}$ & $\begin{array}{l}0.020 \\
(0.03) \\
\end{array}$ & $\begin{array}{l}-0.341 * * * \\
(0.09)\end{array}$ & $\begin{array}{l}0.002 \\
(0.02) \\
\end{array}$ \\
\hline $\begin{array}{l}\text { Share highly- } \\
\text { qualified workers }\end{array}$ & -- & -- & $\begin{array}{c}-7.300 \\
(4.58) \\
\end{array}$ & $\begin{array}{l}0.984 \\
(0.78) \\
\end{array}$ & $\begin{array}{l}2.804 \\
(9.23) \\
\end{array}$ & $\begin{array}{c}-0.587 \\
(2.41) \\
\end{array}$ & $\begin{array}{l}0.547 \\
(3.86) \\
\end{array}$ & $\begin{array}{l}0.260 \\
(1.07) \\
\end{array}$ \\
\hline Agriculture & -- & -- & $\begin{array}{l}13.498 * \\
(7.68)\end{array}$ & $\begin{array}{l}-2.184 * * \\
(0.87)\end{array}$ & $\begin{array}{l}23.380 * * * \\
(10.26)\end{array}$ & $\begin{array}{c}-0.966 \\
(1.64)\end{array}$ & $\begin{array}{l}12.575 * * * \\
(3.16)\end{array}$ & $\begin{array}{c}-0.899 \\
(0.83)\end{array}$ \\
\hline Mining & -- & -- & $\begin{array}{l}6.539 * * * \\
(1.36)\end{array}$ & $\begin{array}{l}-0.459 * \\
(0.25)\end{array}$ & $\begin{array}{l}2.610 * \\
(1.51)\end{array}$ & $\begin{array}{c}-0.067 \\
(0.45) \\
\end{array}$ & $\begin{array}{l}4.430 * * \\
(1.76)\end{array}$ & $\begin{array}{c}-0.259 \\
(0.31) \\
\end{array}$ \\
\hline Constant & -- & -- & $\begin{array}{l}3.241 \\
(5.52)\end{array}$ & $\begin{array}{l}2.677 * * * \\
(0.82)\end{array}$ & $\begin{array}{c}-12.012 \\
(8.13)\end{array}$ & $\begin{array}{l}3.529 * * \\
(1.58)\end{array}$ & $\begin{array}{l}0.331 \\
(6.20)\end{array}$ & $\begin{array}{l}1.299 \\
(1.02)\end{array}$ \\
\hline NOBS & -- & -- & 184 & 184 & 71 & 71 & 85 & 85 \\
\hline $\mathrm{R}^{2}$ & -- & -- & 0.6417 & 0.6024 & 0.6909 & 0.7186 & 0.7291 & 0.5980 \\
\hline
\end{tabular}

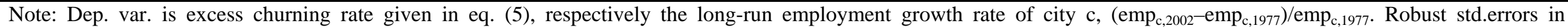
parentheses. Further controls (coefficients omitted for brevity) are: empl. shares large and medium-sized firms, average age of employees, fraction of men, wage, local employment shares of all other industries not reported above. Full results including all estimated coefficients are reported in appendix C. 
Appendix C: Full results tables

\begin{tabular}{|c|c|c|c|c|c|c|c|c|c|c|c|c|c|c|}
\hline & \multicolumn{2}{|c|}{ ALL CITIES } & \multicolumn{2}{|c|}{ GROWING CITIES } & \multicolumn{2}{|c|}{ DECLINING CITIES } & \multicolumn{2}{|c|}{$\begin{array}{l}\text { REINVENTION } \\
\text { CITIES }\end{array}$} & \multicolumn{2}{|c|}{ HIGH-FLYERS } & \multicolumn{2}{|c|}{$\begin{array}{ll}\text { STRUC. } & \text { CHANGE } \\
\text { LOSERS } & \end{array}$} & \multicolumn{2}{|c|}{ DEPRESSED CITIES } \\
\hline & $\begin{array}{l}\text { Churning } \\
\text { (1) }\end{array}$ & $\begin{array}{l}\text { Growth } \\
(2)\end{array}$ & $\begin{array}{l}\text { Churning } \\
\text { (3) }\end{array}$ & $\begin{array}{l}\text { Growth } \\
\text { (4) }\end{array}$ & $\begin{array}{l}\text { Churning } \\
(5)\end{array}$ & $\begin{array}{l}\text { Growth } \\
\text { (6) }\end{array}$ & $\begin{array}{l}\text { Churning } \\
\text { (7) }\end{array}$ & $\begin{array}{l}\text { Growth } \\
\text { (8) }\end{array}$ & $\begin{array}{l}\text { Churning } \\
\text { (9) }\end{array}$ & $\begin{array}{l}\text { Growth } \\
(10)\end{array}$ & $\begin{array}{l}\text { Churning } \\
\text { (11) }\end{array}$ & $\begin{array}{l}\text { Growth } \\
\text { (12) }\end{array}$ & $\begin{array}{l}\text { Churning } \\
\text { (13) }\end{array}$ & $\begin{array}{l}\text { Growth } \\
\text { (14) }\end{array}$ \\
\hline SIZE (log) & $-.722 * * *$ & .0141 & $-.731^{* * *}$ & $-.084 * * *$ & $-.708^{* * *}$ & $.027^{* *}$ & $-.495^{* *}$ & -.076 & $-.413^{* * *}$ & $-.132 * *$ & $-.857 * * *$ & .020 & $-.341 * * *$ & .002 \\
\hline $\mathrm{HQ}$ & -1.721 & $3.514 * * *$ & 2.383 & $6.015^{* * *}$ & -7.300 & .984 & -14.341 & $21.217^{* * * *}$ & $11.018^{* *}$ & 3.100 & 2.804 & -.587 & .547 & .026 \\
\hline $\mathrm{Q}$ & -.878 & .187 & -1.865 & .041 & -.036 & .045 & $-3.951 *$ & .901 & .015 & -.277 & -2.751 & .504 & 1.539 & -.227 \\
\hline LARGE & -.242 & $-1.652^{* * *}$ & $\begin{array}{l}-.034 \\
\end{array}$ & $-.845^{*}$ & -1.128 & -.352 & -1.670 & $\begin{array}{l}-1.773^{*} \\
\end{array}$ & $3.127^{* *}$ & -1.107 & 1.890 & $\begin{array}{l}-.244 \\
\end{array}$ & $2.707^{* *}$ & -.317 \\
\hline MEDIUM & $-4.903 * * *$ & $-1.505^{* * *}$ & $-4.860 * *$ & $-1.143^{*}$ & -6.269 & -.111 & -4.014 & $-3.330 * *$ & 1.651 & -.280 & 1.295 & -.285 & -.373 & -.032 \\
\hline AGE & -.009 & $-.081 * * *$ & .036 & -.032 & -.063 & $-.053^{* * *}$ & .068 & -.035 & -.016 & -.056 & .024 & $-.034 *$ & .080 & $-.027 * *$ \\
\hline MEN & $-2.899 * *$ & $\begin{array}{l}-.822 \\
\end{array}$ & -1.847 & -.567 & $-3.697 * *$ & -.178 & 1.141 & .305 & .357 & -.751 & -.792 & -.169 & -.218 & -.336 \\
\hline WAGE(log) & 1.379 & .428 & -1.646 & .637 & $3.125^{* *}$ & .009 & -.708 & -.257 & -1.722 & .626 & $5.925^{* * *}$ & -.434 & -.109 & .204 \\
\hline 1 Agriculture & $11.965^{* *}$ & $-2.339 * *$ & 9.058 & -.120 & $13.498^{*}$ & $-2.184^{* *}$ & -12.415 & 2.528 & -.001 & -1.342 & $23.380^{* * *}$ & -.965 & $12.575^{* * *}$ & -.899 \\
\hline 2 Energy & -1.550 & .749 & -2.452 & 2.866 & -5.293 & -.720 & -5.093 & $4.672 *$ & -14.899 & -2.787 & -7.210 & -.961 & -6.600 & .752 \\
\hline 3 Metalic mining & $4.337 * * *$ & .189 & 1.265 & $1.320 * *$ & $6.539 * * *$ & $-.459 *$ & .856 & 1.207 & -5.224 & 2.844 & $2.610^{*}$ & .067 & $4.431^{* *}$ & -.259 \\
\hline 4 Chemicals & -1.321 & $.826 * * *$ & -2.743 & $1.296 *$ & -.401 & .160 & -1.308 & .351 & $-2.547 * *$ & $2.360^{* * *}$ & -1.421 & .393 & 2.943 & .510 \\
\hline 5 Synth. material & -.595 & $.611^{*}$ & -2.978 & 1.064 & .616 & .133 & 2.294 & -.745 & -1.038 & $1.943^{* *}$ & $-2.232 *$ & .027 & $5.178 * * *$ & .547 \\
\hline 6 Mineral mining & $5.427 * * *$ & $1.631^{* *}$ & 3.121 & 1.478 & 4.230 & .174 & -2.176 & 1.294 & $10.080^{*}$ & 1.843 & 5.795 & -.728 & $4.978 * *$ & .741 \\
\hline 7 Ceramics/Glass & -1.339 & .296 & .407 & 1.195 & $\begin{array}{l}-.479 \\
\end{array}$ & -.085 & 4.034 & .631 & $-5.217 * *$ & 1.546 & -2.541 & .170 & .485 & -.172 \\
\hline 8 Metal manuf. & .194 & $.780 * * *$ & -.656 & $1.741^{* *}$ & .512 & -.015 & 1.846 & -.741 & -1.704 & $3.039 * * *$ & .345 & .238 & -.964 & .198 \\
\hline 9 Machinery & -.900 & $.907 * * *$ & -1.587 & $1.454 * *$ & -.185 & .073 & $\begin{array}{l}-892 \\
\end{array}$ & .795 & -.659 & $1.721^{* *}$ & $-4.153^{* * *}$ & .427 & $\begin{array}{l}-369 \\
-.36\end{array}$ & .211 \\
\hline 10 Automobile & -.729 & $1.369 * * *$ & -2.081 & $1.705^{* *}$ & 1.146 & $.469 * * *$ & -.485 & -.474 & $-2.036^{*}$ & $2.633^{* * *}$ & $-2.601^{* *}$ & $.768^{* *}$ & .255 & .304 \\
\hline 11 Optics/IT & -1.152 & $.651^{* *}$ & $-3.861^{* *}$ & $1.248^{*}$ & .225 & .217 & -2.437 & 1.608 & -2.122 & $1.357^{* *}$ & .697 & .486 & .832 & .169 \\
\hline 12 Jewelry/Toys & .494 & .042 & -2.341 & 1.338 & 1.767 & $-.455^{*}$ & -3.760 & 1.767 & 1.608 & 1.956 & -1.116 & -.544 & .317 & .023 \\
\hline 13 Wood & 1.110 & $1.135^{* * *}$ & -1.292 & $2.608^{* *}$ & 2.242 & $.449 * *$ & -3.639 & 2.516 & -.762 & $2.657^{* * *}$ & $\begin{array}{l}-.632 \\
\end{array}$ & .972 & .554 & .346 \\
\hline 14 Paper/Printing & .245 & .755 & -.595 & $1.707 *$ & .934 & .117 & 2.105 & -1.076 & -3.587 & $2.694 * *$ & -4.782 & .849 & 1.201 & -.162 \\
\hline 15 Leather/Textile & .091 & 277 & -.572 & $1.697 * *$ & 1.075 & -.221 & -.945 & 1.273 & -.821 & $2.067 * * *$ & .251 & -.177 & 1.042 & .004 \\
\hline 16 Food & -2.149 & $1.891^{* * *}$ & $-4.124 *$ & $2.247 * *$ & -.860 & $1.268 * * *$ & -4.448 & 1.376 & -1.974 & $2.735^{* *}$ & -2.337 & .693 & -.287 & .566 \\
\hline 17 Construction & 1.092 & $1.796 * * *$ & -1.331 & $2.308^{* * *}$ & 1.527 & $.760^{* *}$ & -2.111 & .702 & 1.323 & 1.342 & -.885 & .703 & .083 & .539 \\
\hline 18 Commerce & .785 & $.830^{*}$ & 1.497 & $2.393 * *$ & .898 & -.0441 & 4.416 & 1.095 & -2.175 & $3.501 * *$ & .807 & -.206 & -1.332 & .435 \\
\hline 19 Transportation & 3.161 & $\begin{array}{l}.082 \\
\end{array}$ & -3.094 & .734 & 3.823 & -.332 & -8.615 & -1.304 & -.531 & $2.721 *$ & 1.473 & $\begin{array}{ll}-631 \\
\end{array}$ & 2.469 & -.501 \\
\hline 20 Banking/Insur. & -1.718 & .678 & -5.423 & .843 & -.032 & .063 & -4.435 & -.932 & -2.968 & $2.317^{* *}$ & 6.583 & 1.175 & 2.677 & -.503 \\
\hline 21 Gastronomy & $-5.062 * * *$ & $-1.704 * *$ & $-5.926 *$ & .313 & $-5.294 *$ & -.457 & -7.394 & -1.384 & $\begin{array}{l}-.983 \\
\end{array}$ & .830 & -3.762 & -.895 & -1.813 & -.426 \\
\hline 22 Health Care & $-4.456 * *$ & -1.009 & $-6.809 * *$ & .759 & -3.099 & -.383 & -6.412 & -1.028 & -4.436 & 2.366 & -5.583 & .178 & 4.298 & .242 \\
\hline 23 Business serv. & $4.836^{*}$ & -.706 & -1.525 & -1.039 & 9.345 & .281 & .868 & $-5.400^{*}$ & 6.135 & -1.208 & 1.024 & .553 & -5.742 & 1.799 \\
\hline 24 Education & 2.812 & .703 & 2.239 & 4.393 & 3.694 & .196 & 6.164 & $\begin{array}{l}-271 \\
\end{array}$ & $-11.821^{* *}$ & $8.212^{* * *}$ & .545 & 1.938 & -.401 & .472 \\
\hline 25 Leisure serv. & -3.675 & $2.91 * * *$ & -11.356 & 1.408 & -1.665 & $1.543 * * *$ & -13.187 & 6.311 & -5.279 & 2.315 & -9.950 & 3.340 & -4.007 & .327 \\
\hline 26 Household srv. & 8.487 & -.563 & 19.152 & -8.260 & 5.340 & .410 & 31.447 & $-20.641^{* *}$ & $39.442^{* *}$ & -12.623 & -29.323 & 3.719 & $36.893 * *$ & -.041 \\
\hline 27 Social serv. & 3.397 & 1.557 & -.264 & 2.426 & 6.761 & .735 & 1.382 & -.734 & .567 & 1.750 & -1.167 & -3.060 & 3.167 & .916 \\
\hline CONSTANT & $8.469^{* *}$ & $2.949^{* * *}$ & $20.688^{* * *}$ & .250 & 3.241 & $2.678 * * *$ & 13.258 & 4.617 & $12.868^{*}$ & 1.297 & -12.012 & $3.529^{* *}$ & .331 & 1.299 \\
\hline$\overline{\mathrm{R}^{2}}$ & 0.6222 & 0.6387 & 0.7189 & 0.5105 & 0.6417 & 0.6024 & 0.6039 & 0.7306 & 0.6849 & 0.7804 & 0.6909 & 0.7186 & 0.7291 & 0.5980 \\
\hline
\end{tabular}

Note: ${ }^{* *}$ ) significant at $1 \%$-level, ${ }^{* *}$ ) 5\%-level, *) 10\%-level. Standard errors omitted for expositional purposes. Variable abbreviations are explained in appendix A. 